\title{
MINERALOGY OF DIAMONDS FROM THE JUIINA KIMBERLITE PROVINCE, SW AMAZON CRATON, BRAZIL: CATHODOLUMINESCENCE, INFRARED SPECTROSCOPY, NITROGEN CONTENT, AND CARBON AND NITROGEN ISOTOPES
}

\author{
DÉBORA P. ARAÚJO ${ }^{1}$, JOSÉ C. GASPAR ${ }^{1}$, YINGWEI FEI ${ }^{2}$, ERIK H. HAURI ${ }^{3}$ \& RUSSELL HEMLEY ${ }^{2}$
}

\begin{abstract}
The Mineralogy of 234 primary and alluvial diamonds from the Juína Kimberlite Province has been investigated. The majority of diamonds exhibit low CL intensity and typical blue-sky color. Internal features are rare. The spectral classification of diamonds yields $82 \%$ of Type II stones ( $\mathrm{N}$-free) and a minor amount of highly aggregated Type I diamonds. $\delta^{13} \mathrm{C}$ in Type II diamonds varies from -3 to $-26.3 \% o$ and in Type I from -3.4 to $-13.8 \%$. $\delta^{15} \mathrm{~N}$ in Type I diamonds ranges from +2.2 to $-14.0 \%$ and the $\mathrm{N}$ content, from 3.85 to 613.74 at. ppm. C and $\mathrm{N}$ isotopic compositions are compared to worldwide occurrences and to deep diamond assemblages. The incorporation of $\mathrm{N}$ by deep diamonds and the contribution of subducted terrains of the SW border of the Amazon Craton on the formation of the light ${ }^{1.3} \mathrm{C}$ diamonds are briefly discussed.
\end{abstract}

Keywords: diamond, cathodoluminescence, infrared, C and $\mathrm{N}$ isotopes, SIMS Juina.

INTRODUCTION The Juína Kimberlite Province at the SW border of the Amazon Craton, Brazil, is a well-known site for deep diamonds originated in the transition zone (TZ) and lower mantle (LM), found in the São Luiz River (Wilding et al. 1991, Harte and Harris 1994, Hutchison 1997) and other local drainages (Kaminsky et al. 2001). In this study we investigated the mineralogical characteristics of 234 alluvial and primary diamonds from Juína according to their cathodoluminescence (CL) features, infrared spectral classification, $\mathrm{C}$ and $\mathrm{N}$ isotope and $\mathrm{N}$ content (Araújo 2002). Results obtained here reinforce the origin of Juína diamonds in the deep mantle and contribute with new data to the understanding of this important occurrence. The geological setting of the province is detailed in this volume (Araújo et al. 2001).

METHODS Primary and alluvial diamonds were kindly provided by RTDM Ltd and De Beers Brasil Ltd. 188 primary diamonds from 3 kimberlites and alluvial stones from the rivers São Luiz ( 10 stones), Duas Barras (8 stones), Porcão (8 stones) and Cinta Larga (20 stones) were examined. CL images were obtained from 128 pieces of diamonds and 32 plates using an ELM-3R Nuclide Corporation luminoscope at the Geosciences Institute of University of São Paulo (Brazil) and at the Department of Mineral Science of the Smithsonian Institution (Washington, D.C., USA). CL images from both sides of the plates were generated in order to check for matching features for further Infrared (IR) investigation. All diamonds were measured for IR using a FTIR (Fourier transform Infra Red) Bio Radius Excalibur espectrometer at the SI. In situ variation of carbon and nitrogen isotopic and $\mathrm{N}$ content of 20 diamonds were measured through secondary mass ion spectroscopy at the Carnegie Institution of Washington (Washington D.C., USA). Analytical methods are detailed in Araújo (2002) and Araújo et al. (in preparation).

RESULTS Diamonds are mostly resorbed tetrahexahedroid and irregular fragments, though regular octahedral and macles are also described. The morphology features of the Juína diamonds are detailed in Araújo et al. (2001; this volume). Primary and alluvial diamonds could not be distinguished by their mineralogical characteristics.

CL images for most of the diamonds present typical bluesky color, but with low intensity. The majority of the stones exhibit homogeneous CL patterns. Rare internal features were observed, comprising octahedral growth zones, step-wise growth, truncated growth zones and fine parallel lines, the latter two features being evidence for resorption and deformational processes. Resorption after-growth features revealed by $\mathrm{CL}$ images, are common amongst the Juina diamonds, which agrees with the resorbed and corroded morphological character of these stones.

Type II diamonds (N-free) dominate among alluvial and primary stones $(82 \%)$. The minority of Type I diamonds have low-N content (up to $~ 300$ at. ppm, except for one sample with 


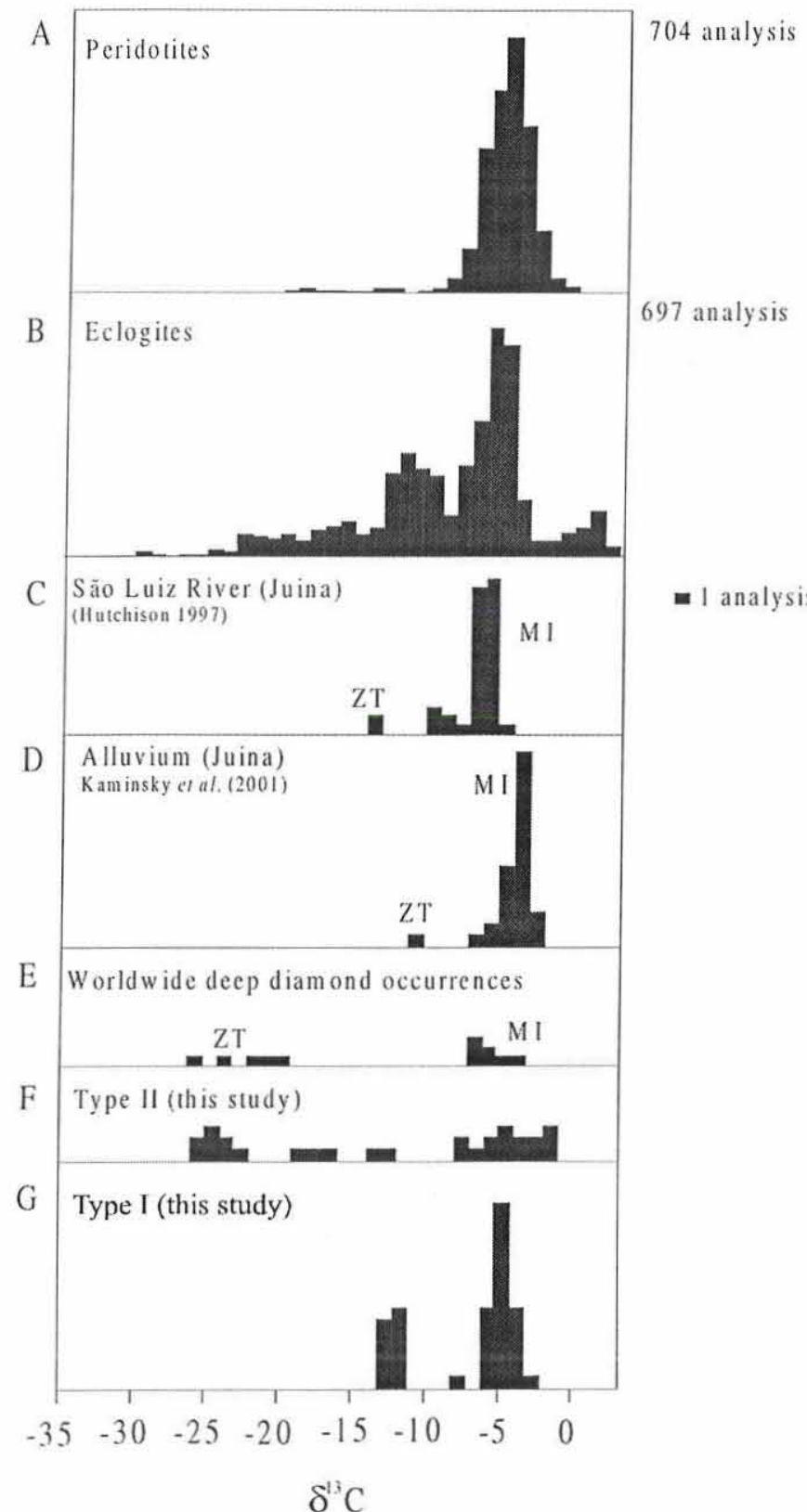

Figure 1 - Carbon isotopic variation for upper mantle and deep diamond worldwide occurrences and for the Juina Kimberlite Province (this study and previous results). Note the different scale for the fields A-B and C-G: A) Peridotites - 704 analysis; B) Eclogites - 697 analysis (Cartigny et al. 1999); C) LM and TZ diamonds from the São Luiz River, Juina Province (37 analysis; Hutchison et al. 1999); D) LM and TZ alluvial diamonds from Juina reported by Kaminsky et al. (2001;30 analysis); E) worldwide deep diamond occurrences (12 analysis; see text for localities and references); F) Type II diamonds (this work; 28 analysis in 14 stones) and G) Type I diamonds (this work; 45 analysis in 6 stones).
613 at. ppm) and were classified as $\mathrm{Ia} A B$ (24 stones) and $\mathrm{IaB}$ (6 stones). Except for three samples, IaAB diamonds are highly aggregated (>90\%). The abundance of Type II diamonds is in accordance with the observed low intensity $\mathrm{CL}$, considering that the latter is directly related to $\mathrm{N}$ content.

$\delta^{13} \mathrm{C}$ in Type II diamonds varies from -3 to $-26.3 \%$ and in Type I from -3.4 to $-13.8 \%$. $\delta \delta^{15} \mathrm{~N}$ in Type I diamonds ranges from +2.2 to $-14.0 \%$ and the $\mathrm{N}$ content, from 3.85 to 613.74 at. $\mathrm{ppm}$.

DISCUSSIONS AND CONCLUSIONS The $\delta^{13} \mathrm{C}$ data for Type I and Type II diamonds (this study) are compared in Figure 1 to those of worldwide peridotite and eclogite assemblages (Cartigny et al.1999) and to deep diamonds from Juína (Hutchison 1997 and Kaminsky et al. 2001) and from worldwide occurrences: Koffiefontein, Jagersfontein (Deines et al. 1991), Guinea (Hutchison 1997) and Lac de Gras (Davies et al. 1999). Our results suggest the existence of four sets of data concentrated near $-5 \%,-13 \% ;-18 \%$ and $-25 \%$, where Type I diamonds belong only to the first two groups (Figure 1). We, however, do not exclude the possibility that blanks in this interval could be attributed to lack of sampling. The $\delta^{13} \mathrm{C}$ interval obtained here is expanded toward lighter values when compared to previous results for the province (Figure 1): Hutchison (1997) and Kaminsky et al. (2001) observed two sets of data, one distributed near $-5 \%$ and the other in the range -11 to $-13 \%$. Transition zone (TZ) diamonds have been related to both groups while lower mantle (LM) diamonds concentrated around $-5 \%$, indicating the homogeneous carbon isotopic character of the LM (Hutchison 1997 and Kaminsky et

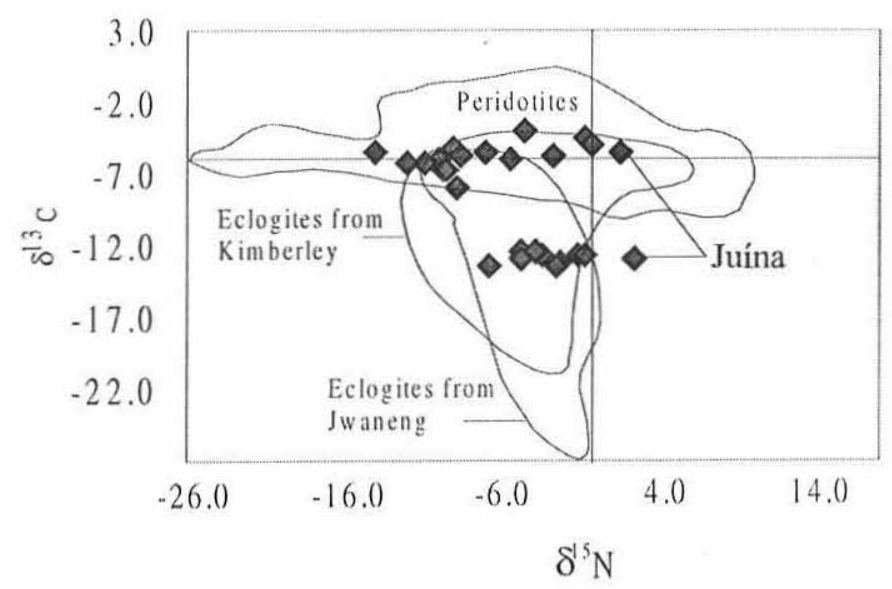

Figure 2 - Co-variation of $\delta^{13} \mathrm{C}-\delta^{15} \mathrm{~N}$ for diamond occurrences. Fields for worlwide peridotite and for eclogites from Kimberley and Jwaneng are from Cartigny et al. (1998a and 1998b). Filled symbols are Type I diamonds from this study. The vertical line is the atmospheric $\delta^{15} \mathrm{~N}$ value (Mariotti 1983) and the horizontal line is the primordial composition for $\delta^{13} C(-4.6 \%)$. 
al. 2001). Data for worldwide LM diamonds also cluster around $-5 \%$ (Fig. 1) while TZ diamonds from Jagersfontien, South Africa, are in the range -20 to $-25 \%$ o (Deines et al. 1991).

The $\delta^{15} \mathrm{~N}$ composition for the Juína diamonds $(+2.2$ to $14.0 \%$ ) encloses previous results from Hutchison et al. (1999), who reported $-5.2 \%$ and $-6 \%$ for $\mathrm{LM}$ stones and $+1.3 \%$ and $+1.2 \%$ for TZ diamonds. Wide compositional intervals were observed here for single diamonds (e.g. -14 to $-2.9 \%$ and $9.6 \%$ to $+2.2 \% o$ ), and are within the compositional $\delta^{15} \mathrm{~N}$ range for worldwide diamond occurrences, as seen in Figure 2. Wide intervals have also been reported for diamonds from Mir and Udachynaya, Russia (Hauri et al. 1999; Fig. 2). The ample $\delta^{15} \mathrm{~N}$ variation for single stones and the observed oscillatory patterns suggest the high sensibility of the nitrogen isotopic system in diamonds. Taking this evidence into account, one should be cautious when using positive $\delta^{15} \mathrm{~N}$ to trace re-cycled carbon.

As observed for deep diamond assemblages, the Juína Kimberlite Province contains a high percentage of Type II diamonds (82\%) and highly aggregated Type I stones, indicating high temperature and/or long time of mantle residence. Considering the rarity of Type II diamonds in the upper mantle and the high aggregation of $\mathrm{N}$ in Type I diamonds, we suggest that the majority of the diamonds investigated here originated in the LM and TZ.
The abundance of Type II diamonds in the TZ and LM suggests the existence of specific conditions that avoid $\mathrm{N}$ incorporation by diamonds. The formation of osbornite (TiN) and sinoite $\left(\mathrm{Si}_{2} \mathrm{~N}_{2} \mathrm{O}\right)$ and/or $\mathrm{N}$ exsolved in silicates are suggested in the literature. An alternative explanation for $\mathrm{N}$ free diamond formation is the high temperature of $\mathrm{TZ}$ and LM. This is suggested here based on diamond synthesis experiments performed by Burns et al. (1999) who showed a decrease in $\mathrm{N}$ incorporation by diamond as $\mathrm{N}$ solubility of the environment increases. The latter, in turn, increases with temperature.

The light composition of $\delta^{13} \mathrm{C}$ for Type II diamonds, down to $-26,3 \%$, may indicate that the TZ bellow the SW Amazon Craton was influenced by recycled carbon, which would be in accordance with subduction activity related to the Rondoniana Santo Ignácio and Sunsás terrains between 1.5 to $1.0 \mathrm{Ga}$ at the SW border of the Amazon Craton.

Acknowledgements The authors are greatly thankful to RTDM Ltd. and De Beers Brasil Ltd. for providing the diamonds for this study, to Gergely Szabó of the University of São Paulo and to Jamies Rougvie of the Smithsonian Institution for CL images, to Richards Wysoczanski of the Smithsonian Institution for Infra Red measurements, and to Galina Bulanova for comments on $\mathrm{CL}$ images. To RBG reviewers for suggestions to the manuscript.

\section{References}

Araújo D.P. 2002. Mineralogia dos diamantes da Província Kimberlítica de Juína. $\mathrm{PhD}$ thesis. Universidade de Brasília. Brasília, Brasil.

Araújo D.P., Gaspar J.C., Bizzi L.A. 2001. Morphology and surface textures and diamonds from the Juína Kimberlite Province, Brazil. Ver. Bras. Geoc., 31:

Cartigny P., Harris J.W., Javoy M. 1998a. Eclogitic diamond formation at Jwaneng: No room for a recycled component. Science, 280:1421-1424.

Cartigny P., Harris J.W., Phillips D., Boyd S.R., Javoy M. 1998b. Subductedrelated diamonds? - The evidence for a mantle derived-origin from coupled $\mathrm{d}^{13} \mathrm{C}-\mathrm{d}^{15} \mathrm{~N}$ determinations. Chem. Geol., 147:147-159.

Cartigny P., Harris J.W., Javoy M. 1999. Eclogitic, peridotitic and metomorphic diamonds and the problems of carbon recycling - The case of Orapa (Botswana). In: IKC, International Kimberlite Conference, 7. Proceedings. J.J. Gurney, J.L. Gurney, M.D. Pascoe, and S.H. Richardson (eds.).VI: 117 124.

Deines P., Harris J.W., Gurney J.J. 1991. The carbon isotopic composition and nitrogen content of lithospheric and asthenospheric diamonds from the Jagersfontein and Koffiefontein kimberlite, South Africa. Geochim. Cosmoch. Acta. 55:2615-2625.

Davies R.M., Griffin W.L., Pearson N.J., Andrew A.S., Doyle B.J., O'Reilly S.Y. 1999. Diamonds from the deep: Pipe DO-27, Slave Craton, Canada. In: IKC, International Kimberlite Conference, 7. Proceedings. J.J. Gurney, J.L. Gurney, M.D. Pascoe, S.H. Richardson (eds.).V1:148-155

Gaspar J.C., Teixeira N.A., Steele I.M. 1998. Cathodoluminescence of Juina Diamonds. In: IKC, International Kimberlite Conference, 7. Extended Abstracts.:242-244.
Harte B. \& Harris J.W. 1994. Lower mantle mineral associations preserved in diamonds. Mineral. Mag. 58A: 384-385.

Hauri E.H., Pearson D.G., Bulanova G.P., Milledge H.J. 1999. Microscale variations in $\mathrm{C}$ and $\mathrm{N}$ isotopes within mantle diamonds revealed by SIMS. In: IKC, International Kimberlite Conference, 7. Proceedings. J.J. Gurney, J.L. Gurney, M.D. Pascoe \& S.H. Richardson (eds.).V1:341-347.

Hutchison M.T. 1997. Constitution of the deep transition zone and lower mantle shown by diamonds and their inclusions. PhD thesis. Edinburgh, UK.

Hutchison M.T., Cartigny P., Harris J.W. 1999. Carbon and nitrogen composition and physical characteristics of transition zone and lower mantle diamonds from São Luiz, Brazil. In: IKC, International Kimberlite Conference, 7 , Proceedings. J.J. Gurney, J.L. Gurney, M.D. Pascoe, and S.H. Richardson (eds.).V1:372-382.

Kaminsky F.V., Zakharchenko O.D., Davies R., Griffin W.L., KhachatryanBlinova G.K., Shiryaev A.A. 2001. Super deep diamonds from the Juina area, Mato Grosso State, Brazil. Contrib. Mineral. Petrol, 140:734-753.

Mariotti A. (1983) Atmospheric nitrogen is a reliable standard for natural $15 \mathrm{~N}$ abundance measurements. Nature, 303:685-687.

Wilding M.C., Harte B., Harris J.W. 1991. Evidence for a deep origin for São Luiz diamonds. In: IKC, International Kimberlite Conference, 5. Extended Abstracts:456-4.58.

Manuscrito NB-45 Recebido em 28 de novembro de 2001 Revisão dos autores em 29 de dezembro de 2001 Revisão aceita em 30 de dezembro de 2001 